\title{
High resolution transmission electron microscopy analysis of conical carbon nanotubes formed in the high isostatic pressure apparatus
}

\author{
Boris A. Kulnitskiy ${ }^{\mathrm{a}, \mathrm{b}} \bowtie$, Igor A. Perezhogin ${ }^{\mathrm{a}, \mathrm{b}}$, Dmitriy V. Batov ${ }^{\mathrm{a}}$, \\ Vladimir D. Blank ${ }^{\mathrm{a}, \mathrm{b}}$, Yuriy L. Alshevskiy ${ }^{\mathrm{a}}$ \\ ${ }^{a}$ Technological Institute for Superhard and Novel Carbon Materials, \\ 7a, Tsentralnaya St., Troitsk, Moscow, 108840, Russian Federation, \\ ${ }^{\mathrm{b}}$ Moscow Institute of Physics and Technology State University, \\ 9, Institutskiy Lane, Dolgoprudny, Moscow Region, 141700, Russian Federation \\ $\checkmark$ boris@tisnum.ru
}

\begin{abstract}
Carbon nanotubes with "herringbone" layers structure synthesized in high isostatic pressure apparatus were studied by High Resolution Transmission Electron Microscopy (HRTEM) methods. Seven different values of semi-apex angles of graphene layers were observed in different nanotubes. It is shown that semi-apex angles approximately equal to $5^{\circ}, 15^{\circ}, 25^{\circ}$ и $35^{\circ}$ can be regarded only to the scroll structure of the nanotubes, while $10^{\circ}, 20^{\circ}$ and $30^{\circ}$ can be regarded to both scroll either nested graphene layers curved to cones due to the embedding of the pentagon's to them. Thus, the observation of all (seven) of these values of semi-apex angles testifies presence of scroll nanotubes in the sample under study, though it does not exclude presence of nested-cone nanotubes.
\end{abstract}

Keywords: carbon nanotube; herringbone structure; transmission electron microscopy; grapheme; pentagon; scroll; semiapex angle; cone.

For citation: Kulnitskiy BA, Perezhogin IA, Batov DV, Blank VD, Alshevskiy YuL. High resolution transmission electron microscopy analysis of conical carbon nanotubes formed in the high isostatic pressure apparatus. Journal of Advanced Materials and Technologies. 2021;6(1):10-17. DOI: 10.17277/jamt.2021.01.pp.010-017

\section{Электронномикроскопический анализ высокого разрешения конусных углеродных нанотрубок, формируемых в аппарате высокого изостатического давления}

\author{
Б. А. Кульницкий ${ }^{a, \tilde{\sigma}}$, И. А. Пережогин ${ }^{\mathrm{a}, \tilde{0}}$, Д. В. Батов ${ }^{\mathrm{a}}$, \\ В. Д. Бланк ${ }^{a, \tilde{\sigma}}$, Ю. Л. Альшевский \\ а Технологический институт сверхтвердых и новых углеродных материалов, \\ ул. Центральная, 7а, Москва 108840, Российская Федерация, \\ ${ }^{\sigma}$ Московский физико-технический институт, \\ Институтский пер., 9, Долгопрудньій, Московская область, 141700, Российская Федерация
}

boris@tisnum.ru

\begin{abstract}
Аннотация: Углеродные нанотрубки со структурой слоев «елочка», синтезированные в аппарате высокого изостатического давления, были исследованы методами просвечивающей электронной микроскопии высокого разрешения. В разных нанотрубках наблюдалось семь различных значений полууглов при вершине конуса. Показано, что полууглы при вершине конуса, приблизительно равные $5^{\circ}, 15^{\circ}, 25^{\circ}$ и $35^{\circ}$, можно отнести только к структуре нанотрубок типа «свертки», а $10^{\circ}, 20^{\circ}$ и $30^{\circ}$ - как к «свертке», так и к структуре, образованной вложенными друг в друга конусами, состоящими из слоев графена, изогнутыми в виде конусов из-за встраивания в них пятиугольников. Таким образом, наблюдение всех (семи) из этих значений углов при вершине свидетельствует о наличии нанотрубок типа «свертки» в исследуемом образце, но не исключает наличия нанотрубок с вложенными конусами.
\end{abstract}


Ключевые слова: углеродная нанотрубка; структура типа «елочка»; просвечивающая электронная микроскопия; графен; пятиугольник; свертка; полуугол при вершине; конус.

Для цитирования: Kulnitskiy BA, Perezhogin IA, Batov DV, Blank VD, Alshevskiy YuL. High resolution transmission electron microscopy analysis of conical carbon nanotubes formed in the high isostatic pressure apparatus. Journal of Advanced Materials and Technologies. 2021;6(1):10-17. DOI:10.17277/jamt.2021.01.pp.010-017

\section{Introduction}

Carbon occupies a special position among all the elements in the periodic table because it is the only one that has isomers from zero up to three dimensions [1]. Graphene layers can transform into sphere-like structures (e.g., fullerenes, onions) [2] and cylinderlike structures (nanotubes, nanofibers) [3]. The discovery of carbon nanotubes is probably the most important in materials research at the end of 20 century. Two publications by Iijima [3,4] have generated great interest and inspired an increasing number of researchers around the world to study tubular carbons. Among the numerous kinds of nanotubes, the "herringbone" nanotubes $[5,6]$ formed by conical-shaped graphene, are ones of the most interesting objects. "Herringbone" nanotubes may have nested-cone structure (when seamless conical graphene layers are placed one into another) either scroll structure (as a single wrapped graphene layer). Their electronic properties are very sensitive to the particular geometrical arrangement of atoms. It was shown by Heiberg-Andersen et al. that such nanotubes are characterized by large electrostatic dipole moments [7], and they are promising for many practical applications.

"Herringbone" nanotubes and nanofibers can be obtained by different methods [8]. Herringbone-type carbon nanofibers constructed by stacking graphitic nanocones with different cone angles from $60^{\circ}$ to $180^{\circ}$ have been synthesized in [9] by the CVD method (without using catalyst). Carbon nanotubes were prepared in [10] by aerosol method. The analysis of the apex angles showed that the nanotubes have a scroll-type structure. Scroll-type tubes were prepared by processing multilayer graphene nanoplatelets in a shear deformation diamond anvil high-pressure cell. The mechanism of formation of such a tube can be associated with twisting one or more of the top layers of the graphene stack [11]. Both hollow tubes and tubes containing filler were made in a continuous stream of $\mathrm{CO}$ in a horizontal reactor [12].

Apparently, the type of tubes formed is influenced by numerous factors. Nanofilaments with conical-shaped layers with semi-apex angles $15^{\circ}-20^{\circ}$ and diameter about $100 \mathrm{~nm}$ were made in arc discharge in [13]. "Herringbone" nanotubes were made in [14] at temperature $800 \mathrm{~K}$ in the process of methane decomposition on $\mathrm{Ni} / \mathrm{SiO}_{2}$ substrate.
In [15] one of the possible causes of conical layers formation in "herringbone" nanotube is considered to be hydrogen, because it is known that hydrogen atoms can be adsorbed at dangling bonds of carbon.

Nitrogen-containing nanotubes have characteristic morphological peculiarities associated with irregular wavy and corrugated surfaces and cuplike features, consisting of compartmentalised 'stacked cones' or nested cone-type stacking of graphene sheets (bamboo-like structure) [16].

In the present work we analyze "herringbone" nanotubes prepared in high isostatic pressure apparatus (HIP). The mechanisms of their formation are discussed taking into consideration high resolution transmission electron microscopy (HRTEM) data.

\section{Methods and materials}

Carbon nanotubes were prepared in water cold HIP apparatus under nitrogen pressure of $26 \mathrm{MPa}$ [17]. It is known that variations in the thermodynamic conditions in the HIP apparatus affect the size and shape of the grown carbon nanostructures. The heater, made of graphite, were conducting a current of $220 \mathrm{~A}$ under tension 7-10 V. The carbon heater temperature did not exceed $(2250 \pm 50) \mathrm{K}$. The carbon vapour was transported from the hottest zone by convection to the cold zone and was deposited as soot product in the upper part of the heater. Melamine $\left(\mathrm{C}_{3} \mathrm{~N}_{6} \mathrm{H}_{6}\right)$ and ferrocene $\left(\mathrm{Fe}\left(\mathrm{C}_{5} \mathrm{H}_{5}\right)_{2}\right)$ were placed apart in different areas of HIP-chamber. Temperature measurement was performed by means of thermoelectric couple. The maximum temperature in HIP-chamber did not exceed $1100^{\circ} \mathrm{C}$. The temperature in a crucible with ferrocene was about $580^{\circ}-600^{\circ} \mathrm{C}$. The temperature in crucible with melamine was about $980^{\circ}-1000^{\circ} \mathrm{C}$, as at the lateral surface of the heater, where the carbon has deposited. Iron contained in ferrocene served as a catalyst. It is assumed that carbon deposit was yielded not only from the graphite heater but also from melamine $\left(\mathrm{C}_{3} \mathrm{~N}_{6} \mathrm{H}_{6}\right)$. The duration of the experiment was less than 9 minutes. Details concerning the HIP construction can be found in [18]. Electron microscopy analysis was performed by JEM-2010 (TEM) and JSM-7600F (SEM). The specimen was extruded by the needle from the upper part of the heater on the slide plate and then deposited on the grid. 


\section{Results and discussion}

One of the specific features of carbon nanostructure synthesis in HIP is drastic increase of convection, which favors activation of chemic reactions and transfer of the reagents into the areas with different temperature values, which, in its turn, provides a big variety of kinds of synthesized nanostructures. According to the SEM analysis, nanotubes with a diameter of up to $200 \mathrm{~nm}$ and a length of several hundred microns were formed as a result of the experiments (Fig. 1).

The TEM analysis has shown the presence of carbon nanotubes with both cylindrical and conical graphene layers. In spite of the fact, that ferruginous material (ferrocene) was used in our experiment, only few nanotubes contained catalyst particles. Fig 2 shows the microphotograph of the fragments of seven carbon nanotubes with conical layers, obtained by high resolution transmission electron microscopy. It can be seen that the semi-apex angles of graphene cones represent a sequence of values between $5^{\circ}$ and $35^{\circ}$ with $5^{\circ}$-step.

Fig. 3 shows fragments of the edges of the two tubes. This is evidenced by the angles between the fringes at the edges of the nanotubes, which are $50^{\circ}$ and $70^{\circ}$, respectively. The catalytic particles appear to have fallen out during the preparation of the sample. The semi-apex angles are $25^{\circ}$ and $35^{\circ}$, respectively.

The catalytic particles fell out during the preparation of the sample.

As a result of the growth, the cap of the tube was severely deformed, but the corners were preserved. All four angles, shown in the photo, are equal.

Fig. 4 shows a deformed cap of a nanotube in which all four marked angles between the fringes are $40^{\circ}$. As a result of the growth, the cap of the tube underwent severe deformation, but the angles were preserved. The possibility of the existence of internal deformations during the growth of such structures

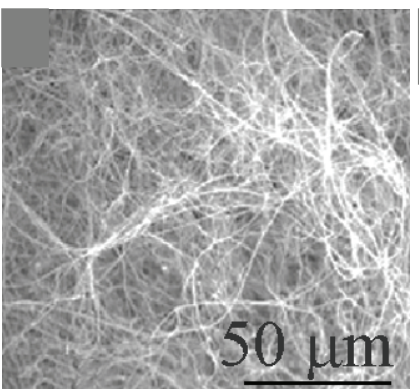

(a)

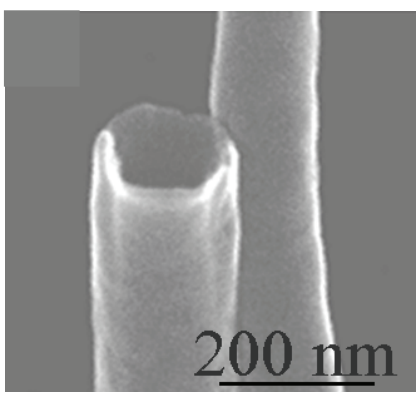

(b)
Fig. 1. Carbon nanotubes synthesized in HIP apparatus: $a$ - main view; $b$ - multiwalled hollow nanotube was assumed in [19]. This can be explained by strong longitudinal deformations that could result from the formation of $\mathrm{sp}^{3}$-bonds along the fiber axis [20]. In some conical tubes, the number of graphene layers varies along the length of the tube.

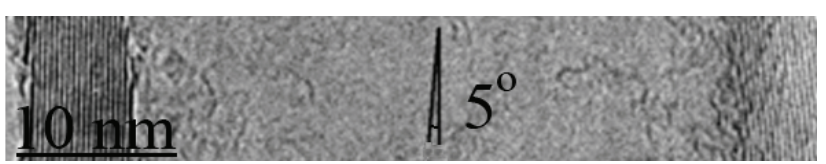

(a)

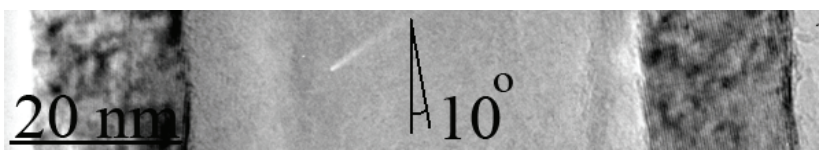

(b)

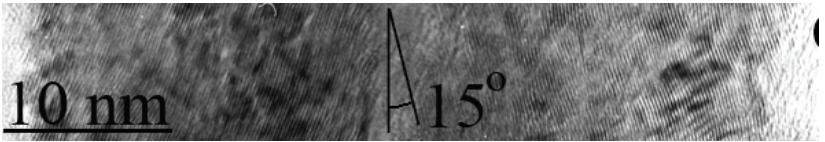

(c)

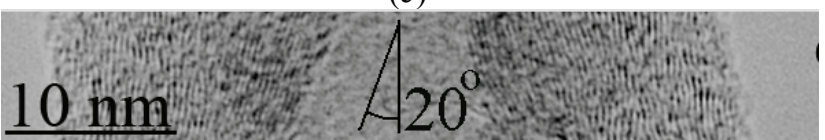

(d)

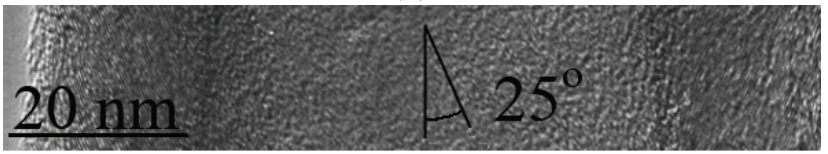

(e)

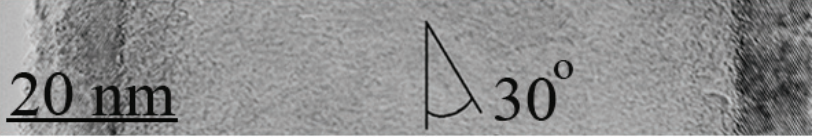

$(f)$

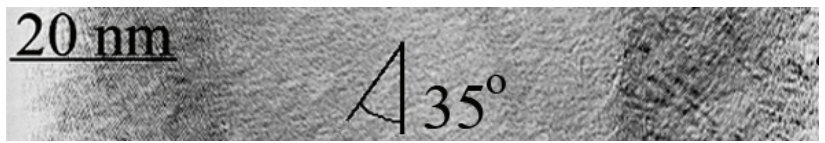

$(g)$

Fig. 2. Fragments of seven carbon nanotubes with layers. The semi-apex angles of graphene cones represent a sequence of values between $5^{\circ}$ and $35^{\circ}$ with $5^{\circ}$-step

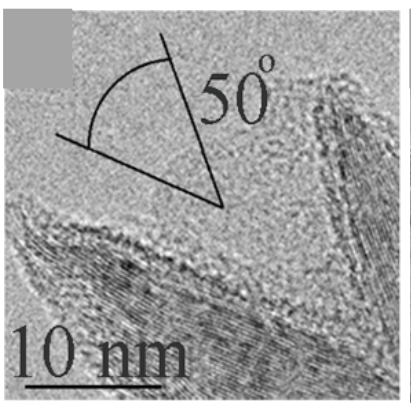

(a)

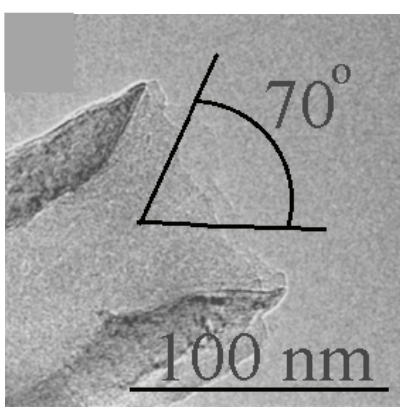

(b)
Fig. 3. Angles of $50^{\circ}$ and $70^{\circ}$ between the fringes at the edges of the nanotubes 


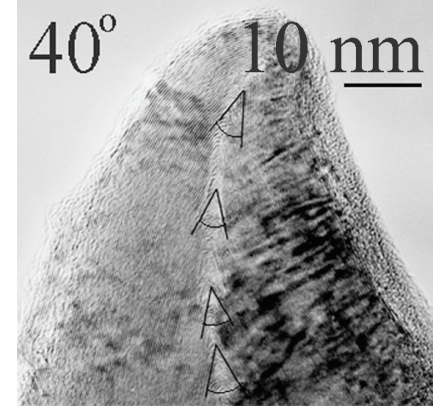

Fig. 4. The cap of the nanotube in which the fringes form an angle of $40^{\circ}$

As can be seen from Fig. 5, a different number of layers are located to the left and right of the tube axis at the same level (20 and 17). This cannot be due to electron microscopic contrast. Figure 6 shows a cylindrical carbon nanotube (right-hand side) that turns twice into a conical one. Arrows indicate areas in which there is a change in angle in the cross section of the tube. The question under consideration is what mechanism of formation of carbon nanotubes with conical graphene layers is. Three models are known to explain the formation of conical nanotubes: the introduction of pentagons into the hexagonal graphene plane, scroll and the disclination model. The disclination model works in the case of wrapping and "overlapping" of graphite surfaces around the disclination. In this case, the adjacent graphene layers differ from each other by the same declination angle. This mechanism gives a wide range of angles, but these angles are not found in the present work.

The symmetry of the graphite planes was considered in [21]. It is known that the nanotube cap can be formed by the pentagons embedding into the structure of graphite (002) plane during the process of nanocarbon synthesis. This effect leads to the bending of the graphite (002) plane and formation of a cone.

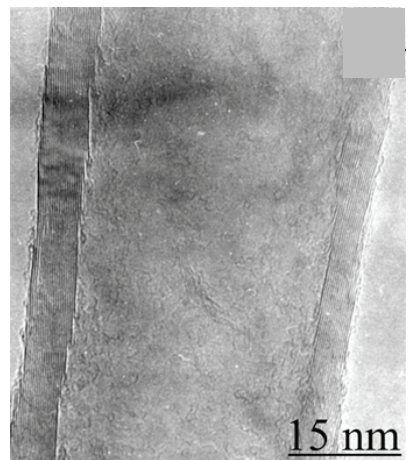

(a)

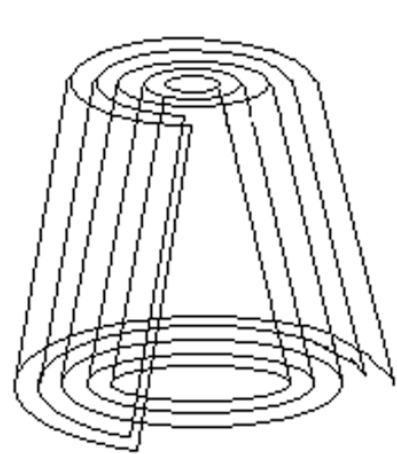

(b)
Fig. 5. The fragment of conical nanotube: $a$-different number of layers to the left and right of the tube axis (20 and 17, respectively); $b-\operatorname{scheme}$ from $(a)$

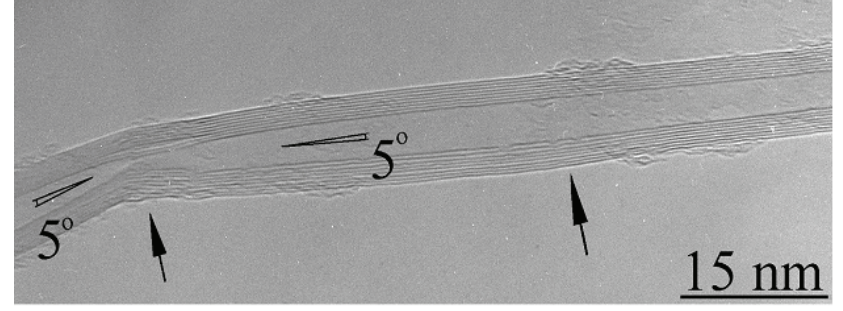

Fig. 6. Cylindrical carbon nanotube twice turning into a conical one. Arrows indicate areas in which there is a change in angle in the cross section of the tube

This is the way of formation of "herringbone" nanotube or nanofiber, consisting of nested cones of graphene. Also "herringbone" nanotube can originate from single graphene layer wrapped as a cone scroll. Such a mechanism was proposed in [22]. The dependence of the semi-apex angle of the graphene cone on the amount of the pentagons embedded in it was determined as $\sin \varphi=1-p / 6$, where $\varphi$ is the semi-apex angle and $p$ is the amount of the pentagons. The amounts of pentagons $5,4,3$, 2, 1 correspond to angles $9.59^{\circ}, 19.47^{\circ}, 30^{\circ}, 42.3^{\circ}$ and $56.5^{\circ}$ [23]. The reasons of formation of pentagons can be different. For example, the atoms of the catalyst material placed into carbon can cause the formation of the pentagons [24], as well as the deformation or changes of temperature and/or pressure during the nanotube growth. If the amount of the pentagons in a nanotube cap attains 6 , the cap becomes a hemisphere and further cylindrical nanotube growths. Twelve pentagons leads to the formation of the fullerenes $\left(\mathrm{C}_{60}, \mathrm{C}_{70}\right.$, etc. $)$ or nanotubulens with hemisphere caps at both ends. Seamless cylindrical nanotubes can be formed as a result of symmetrical wrapping of the graphene sheet in such a way, that carbon hexagons at the edges of the sheet totally coincide after wrapping. Graphene cones can be obtained in the same way, but in this case wrapping occurs asymmetrically, so, that the hexagons at the edge appear to be rotated at certain angle relatively to the ones at the other edge (in previous coil in case of scroll), and this results in formation of conical structure.

Conical scroll can be formed in case of multiple wrapping of single graphene sheet, when edges of the sheet are not connected to one another. New atoms of carbon, depositing on a free edge of a scroll constitute new coil of a scroll. The transversal section of this structure is a helix. In [24] it was shown that the transformation of a graphene sheet into a scroll requires to take into account elastic energy (due to the curvature of the wrapped plane) and Van-der-Vaals bending energy between the neighbor coils in a scroll. 
The calculations of these energies shows, that scroll is more stable object than a plane and more stable than the graphene layer [24].

The time of a scroll formation is about picoseconds and the formation of this structure requires energy, which can be received by the temperature treatment, ultrasonic treatment and by other ways. Carbon hexagons of neighbor layers in a scroll cannot be oriented arbitrarily with respect to one another: the angle of rotation of the hexagons after each coil in scroll relatively to the previous layer should be a multiple of $30^{\circ}$. The dependence of the cone semi-apex angle $\theta$ on the angle of rotation of the hexagons $\alpha$ is given by the formula $\theta=2 \pi \sin \alpha$. The same result is valid for the seamless cones with pentagons [22]. As it can be seen from Table 1, semi-apex angles take only certain values. Only some of these values are the same for both types of structure: scroll and nested cones, formed by pentagons. Such coincidence occurs for angles which are multiple of $60^{\circ}$.

Table 1. Angle of rotation of carbon hexagon relatively to the neighbor layer in conical scroll $\alpha$, semi-apex angle in conical scroll $\theta$,

semi-apex angle in cone with embedded pentagons $\varphi$, amount of pentagons $p$

\begin{tabular}{|c|c|c|c|}
\hline \multicolumn{2}{|c|}{$\begin{array}{l}\text { Scrolls, } \\
\theta=2 \pi \sin \alpha\end{array}$} & \multicolumn{2}{|c|}{$\begin{array}{c}\text { Cones, made by pentagons, } \\
\qquad \sin \varphi=1-p / 6\end{array}$} \\
\hline $\begin{array}{c}\alpha,^{\circ} \\
\text { (hexagon } \\
\text { rotation) }\end{array}$ & $\begin{array}{c}\theta,^{\circ} \\
\text { (semi-apex } \\
\text { angle in } \\
\text { scroll) }\end{array}$ & $\begin{array}{c}\varphi,^{\circ} \\
\text { (semi-apex angle } \\
\text { in cone } \\
\text { with pentagons) }\end{array}$ & $\begin{array}{c}p \\
\text { (amount } \\
\text { of } \\
\text { pentagons) }\end{array}$ \\
\hline 30 & $\underline{4.78}$ & & \\
\hline 60 & $\underline{9.59}$ & $\underline{9.59}$ & 5 \\
\hline 90 & $\underline{14.47}$ & & \\
\hline 120 & $\underline{19.47}$ & $\underline{19.47}$ & 4 \\
\hline 150 & $\underline{24.62}$ & & \\
\hline 180 & $\underline{30}$ & $\underline{30}$ & 3 \\
\hline 210 & $\underline{35.68}$ & & \\
\hline 240 & 41.81 & 41.81 & 2 \\
\hline 270 & 48.59 & & \\
\hline 300 & 56.44 & 56.44 & 1 \\
\hline 330 & 66.44 & & \\
\hline 360 & 90 & & \\
\hline
\end{tabular}

Fig. 2, $b$ shows "herringbone" nanotube with a semi-apex angle approximately equal $10^{\circ}$. This value $\left(9.59^{\circ}\right)$ can be observed in both types of structure, scroll and nested cones, and the same for $20^{\circ}$ and $30^{\circ}$. But $5^{\circ}\left(4.78^{\circ}\right)$ at Fig. 2, $a$ can be attributed only to the scroll, and not to the nested cones (as well, as $15^{\circ}$, $25^{\circ}$ and $35^{\circ}$ ). In case of $5^{\circ}$-semi-apex angle in scroll, hexagons in neighbor layers are rotated at $30^{\circ}$ relatively to one another. This means that the orientation of hexagons in all odd (even) layers is the same.

Apex-angles of $50^{\circ}$ and $70^{\circ}$ between the fringes in the two nanotubes, shown in Fig. 3, $a, b$ correspond to the scroll structure. Fig. 4 shows a deformed cap of a nanotube in which all four marked angles between the fringes are $40^{\circ}$, which can be explained by two growth mechanisms. The structure of the nanotube shown in Figure 5 does not agree with the scroll model, at least in its pure form, and suggests a more complex model. The concentric cones in Fig. 5 were most likely formed initially. But as a result of the fact that it is difficult to achieve equilibrium synthesis conditions in the HIP apparatus, more carbon atoms were deposited from the chemical vapor on one side of the tube than on the other; in addition, small changes in temperature and pressure could prevent the formation of pentagons, as a result of which the outer part of this structure turned out to be a scroll. In this case, the number of layers on different sides of the longitudinal centerline could be different. The different lengths of the truncated cones could also lead to the same phenomenon. In this case, it is possible to form a different number of layers along the length of the cone. Under equilibrium synthesis conditions, a multi-walled carbon nanotube, which is a set of nested cones, is a more stable structure than a scroll. In [25], when carbon nanostructures grow under controlled conditions, changes in the growth mechanisms for the same tube were observed from a concentric structure for the inner parts to a scroll for the outer parts of the tube. The angle of $5^{\circ}\left(\approx 4.78^{\circ}\right)$, in the nanotube shown in Fig. 6, can only correspond to the scroll structure. On the other hand, you can get a cone with an angle of $4.78^{\circ}$ by inserting a heptagon into a structure consisting of hexagons. Thus, the formation of a fragment consisting of a set of hexagons and one heptagon can be a precursor to both a scroll-cone and an ordinary cone, and an angle of $4.78^{\circ}$ can correspond to two different structures.

Hence, every cone appears to consist of not only hexagons, but also pentagons and heptagons, and possibly more complex structures. In the case of concentric cones, all the features of the structure of 
one of them must be repeated for the others. In the case of a scroll cone with an angle of $4.78^{\circ}$, the hexagons in the adjacent layers will be disoriented by an angle of $30^{\circ}$. Hence, the orientations of the hexagons in all even (odd) layers coincide. Heptagon can be formed, for example, by introducing atoms of other elements into the hexagon.

As mentioned earlier, a nested cylinder nanotube is, under equilibrium conditions, the more stable configuration compared to a scroll structure, and the energy difference decreases with increasing diameter and number of graphene layers per wall. In [25] the dynamic change of growth mechanism from nested cylinders for inner part to scroll for outer part was observed during the controllable growth process of carbon nanostructures. The authors suggest that the acceleration of the complete growth kinetics, including decomposition of the ethylene precursor gas, diffusion of carbon atoms through the catalyst, and precipitation of new graphene layers at the surface of catalyst particle, provides the conditions for the change in growth characteristics of one and the same tube. The transition region is characterized by a concentric structure towards the inside of the tube and a scroll-type structure at the outside. In [26] authors considered TEM images of nanotubes, where the amount of graphene layers at the one side of the tube projection was one layer more, than at the left side, and this was explained by the defect in sliding plane. The mechanism of formation of cones by the microclaster embedding in their structure was proposed in [27].

The observation of both types of structures (scroll and nested cones) in our experiment testifies the nonequilibrium of growth conditions. Straight cylindrical nanotubes originate through the catalytic growth and they are always seen in a deposit. The formation of these structures is favored by the small size of the graphene sheets, whereas large graphene sheets are more suitable for formation of scrolls. The formation of the cap with pentagons for the conical scroll is not possible because of incoincidence of semi-apex angles. Discussing the possible mechanisms of the formation of conical nanotubes in the HIP apparatus, we can exclude the disclination model, which assumes a wide range of angles not found in our work. As for the other two models, it is possible to form nanotubes under nonequilibrium conditions in accordance with both models. Scroll whiskers were first reported by Bacon in 1960 [28]. Scrolls possess unusual chemical, mechanical and electronic properties, and they are promising material for many practical applications. They were synthesized under different conditions: in arc discharge [29], by CVD method [9] (with apex angle from $30^{\circ}$ to $110^{\circ}$ ). In [30] carbon nanotubes having a structure of scrolls were formed by polymerization in the interlayer of graphite and the subsequent removal of the polymer. In [31] there were observed nanofibers with conical structure and semi-apex angles $15^{\circ}, 25^{\circ}$ and $35^{\circ}$. Authors explained their formation in terms of an open cone model.

Because of scroll topology, their properties should differ from those of single- or multiwall cylindrical carbon nanotubes. Scroll and nested cone structures can be distinguished by the following way: the studies of nanotube thermal expansion in 20-320 K temperature range [29] have shown that the radial expansion of the nanotubes is almost the same as in graphite along the c-axis of the graphite crystal. Authors have explained this in terms of scroll model. Other distinction of the nested cylinders from the scrolls is the intercalation capability of the last ones [32]: scrolls can be intercalated by $\mathrm{K}, \mathrm{FeCl}_{3}$ and other substances. In [32] it was determined by means of electron spin resonance that the sample powder consisted of both types of structures. Interlayers galleries in scrolls can be intercalated with donors and acceptors, and the nanotube diameter can expand to accommodate the volume of intercalant. This feature is potentially important for a rich variety of applications, from hydrogen storage to energy storage in supercapacitors or batteries. Nanoscrolls have chemical surface reactivity due to large number of edge sites.

At the same time, all the "herringbone" nanotubes with catalyst particles, observed in our experiments always have semi-apex angle which was multiple of $10^{\circ}$. Probably, both of the nanotube formation mechanisms took place in our experiment. In this case, scrolls were originating without catalyst as nanohorns did [33]. The carbon conical nanotubes may have complex band structures and fascinating charge transport properties, from insulating at the apex to metallic at the base. The electronic properties of carbon nanocones were investigated systematically in [35]. The authors described locally the electronic properties as a function of size and symmetry. It was found that the symmetry of the edge sites plays a crucial role in the determination of the electronic structure.

They might be used as building units in future nano-scale electronics devices [34].

\section{Conclusion}

Carbon nanotubes, where graphene layers of shape were obtained in HIP apparatus in mixed atmosphere of argon and nitrogen at temperature $1450 \mathrm{~K}$ and under pressure from 80 to $100 \mathrm{MPa}$. In the process of the TEM studies the nanotubes of the seven different values of the semi-apex angles 
were observed, these values are $5^{\circ}, 10^{\circ}, 15^{\circ}, 20^{\circ}, 25^{\circ}$, $30^{\circ}$ and $35^{\circ}$. Our considerations have shown that the nanotubes with semi-apex angles $10^{\circ}, 20^{\circ}$ and $30^{\circ}$ in the graphene layers in their structure can be attributed to both conical scroll and nested cone structure, originated due to the embedding of the pentagons, whereas nanotubers with semi-apex angles $5^{\circ}, 15^{\circ}$, $25^{\circ}$ and $35^{\circ}$ can be attributed only to cones. The empty cone-shaped structure of graphene walls may be of particular interest for some applications, for example, because of its simplicity for intercalation reactions.

\section{Funding}

This study did not receive external funding.

\section{Conflict of interests}

The authors declare no conflict of interest.

\section{References}

1. Saito R, Dresselhaus G, Dresselhaus MS. Physical properties of carbon nanotubes. London: Imperial College Press; 1998. p. 35-58. DOI:10.1142/9781860943799_0003.

2. Iijima S. Direct observation of the tetrahedral bonding in graphitized carbon black by high resolution electron microscopy. Journal of Crystall Growth. 1980;50(3):675-683. DOI:10.1016/0022-0248(80)90013-5

3. Iijima S. Helical microtubules of graphitic carbon. Nature. 1991;354:56-58. DOI:10.10.38/354056a0

4. Iijima S, Ichihashi T. Single-shell carbon nanotubes of 1-nm diameter. Nature. 1993;363:603-605. DOI: $10.1038 / 363603 \mathrm{a} 0$

5. Endo M, Takeuchi K, Kobori K, Takahashi K, Kroto HW, Sarkar A. Pyrolytic carbon nanotubes from vapor-grown carbon fibers. Carbon. 1995;33(7):873-881. DOI:10.1016/0008-6223(95)00016-7

6. Terrones $H$, Hayashi $T$, Munoz-navia $M$, Terrones M, Kim YA, Grobert N, Kamalakaran R, Dorantes-Davila J, Escudero R, Dresselhaus MS, Endo M. Graphitic cones in palladium catalysed carbon nanofibres. Chemical Physics Letters. 2001; 343:241-250. DOI:10.1016/S0009-2614(01)00718-7

7. Heiberg-Andersen H, Skjeltorp AT, Sattler K. Carbon nanocones: A variety of non-crystalline Solids. Journal of Non-Crystalline Solids. 2008;354:5247-5249. DOI:10.1016/j.jnoncrysol.2008.06.120

8. Schaper A. Carbon Nanoscrolls. In: Blank VD, Kulnitskiy BA. Carbon nanotubes and related structures. Kerala, India: Research Signpost; 2008. p. 2-51.

9. Lin CT, Chen WC, Yen MY, Wang LS, Lee CY, Chin TS, Chiu HT. Cone-stacked carbon nanofibers with cone angle increasing along the longitudinal axis. Carbon. 2007;45:411-415. DOI:10.1016/j.carbon.2006.09.002

10. Kulnitskiy B, Karaeva A, Mordkovich V, Urvanov S, Bredikhina A. TEM studies of scroll carbon nanotubes formed by aerosol synthesis. IOP Conference Series: Materials Science and Engineering. 2019;693:012017. DOI:10.1088/1757-899X/693/1/012017
11. Blank VD, Kulnitskiy BA, Kirichenko AN, Memetov NR, Dyachkova TP, Tkachev AG. Features of structures obtained by grapheme nanoplatelets treatment in a diamond anvil high pressure cell. Fullerenes, nanotubes and carbon nanostructures. 2017;25(8):488-492. DOI:10.1080/1536383X.2017.1339694

12. Kulnitskiy BA, Blank VD. Iron carbide formation inside carbon nanotubes. Advanced Materials \& Technologies. 2017;3:34-39. DOI: 10.17277/amt.2017.03.pp.034-039

13. Fitzgerald JD, Tailor GH, Brunckhorst LF, Pang LSK, Wilson MA. Filaments with microstructures formed during fullerene production. Carbon. 1993;31(1):240-244. DOI:10.1016/0008-6223(93)90181-9

14. Takenaka S, Kobayashi S, Ogihara H, Otsuka K. $\mathrm{Ni} / \mathrm{SiO}_{2}$ catalyst effective for methane decomposition into hydrogen and and carbon nanofiber. Journal of Catalysis. 2003;217:79-87. DOI: 10.1016/S0021-9517(02)00185-9

15. Zhuxin Yu, De Chen B. Totdal B, Holmen A. Effect of catalyst preparation on the carbon nanotube growth. Catalysis today. 2005;100(3-4):261-267. DOI:10.1016/j.cattod.2004.09.060

16. Nath M, Satishkumar BC, Govindaraj A, Vinod CP, Rao CNR. Production of bundles of aligned carbon and carbon-nitrogen nanotubes by the pyrolysis of precursors on silica supported iron and cobalt catalysis. Chemical Physics Letters. 2000;322:333-340. DOI:10.1142/9789812835734_0027

17. Blank VD, Polyakov EV, Batov DV, Kulnitskiy BA, Bangert U, Gutierrrez-Sosa A, Harvey AJ, Seepujak A. Formation of N- containing C-nanotubes and nanofibres by carbon resistive heating under high nitrogen pressure. Diamond and Related Materials. 2003;12:864-869. DOI:10.1016/S0925-9635(02)00378-3

18. Blank VD, Polyakov EV, Kulnitskiy BA, Nuzhdin AA, Alshevskiy YL, Bangert U, Harvey AJ, Davock HJ. Nanocarbons formed in a hot isostatic pressure apparatus. Thin solid films. 1999;346:86-90. DOI: 10.1016/S0040-6090(98)01453-9

19. Bernaerts D, Zhang XB, Zhang XF, Amelinckx S, Van Tandeloo G, Van Landuyt J, Ivanov V, Nagy JB. Electron microscopy study of coiled carbon tubules. Phylosophical Magazine A. 1995;71(3):605-630. DOI: $10.1080 / 01418619508244470$

20. Blank VD, Kulnitskiy BA. Proposed formation mechanism for helically coiled carbon nanofibers. Carbon. 2004;42:3009-3012. DOI:10.1016/j.carbon.2004.06.004

21. Krishnan A, Dujardin E, Treacy MMJ, Hugdahl J, Lynum S, Ebbesen TW. Graphitic cones and the nucleation of curved carbon surfaces. Nature. 1997;388:451-454. DOI: $10.1038 / 41284$

22. Amelinckx S, Devouard B, Baronnet A. Geometrical aspects of the diffraction space of serpentine rolled microstructures: their study by means of electron diffraction and microscopy. Acta Crystallographica. 1996;A52:850-878.

23. Boellard E, DeBokx PK, Kock AJHM, Geus JW. The formation of filamentous carbon on iron and nickel catalysts. Journal of Catalysis. 1985;96:481-490. DOI:10.1016/0021-9517(85)90316-1

24. Braga SF, Coluci VR, Legoas SB, Giro R, Galvao DS, Baughman RH. Structure and dynamics of 
carbon nanoscrolls. Nano Letters. 2004;4:881-884. DOI: $10.1021 / \mathrm{n} 10497272$

25. Sun X, Li R, Stansfield B, Dodelet J-P, Menard G, Desilets S. Controlled synthesis of pointed carbon nanotubes. Carbon. 2007;45:732-737. DOI:10.1016/ j.carbon.2006.11.033

26. Lavin P, Subramoney S, Ruoff R, Berber S, Tomanek D. Scrolls and nested tubes in multiwall carbon nanotubes. Carbon. 2002;40:1123-1130. DOI:10.1016/ S0008-6223(02)00050-7.

27. Lozovik YuE, Popov AM. Formation and growth of carbon nanostructures: fullerenes, nanoparticles, nanotubes and cones. Physics-Uspekhi. 1997;40(7):717-737. DOI:10.3367/UFNr.0167.199707d.0751

28. Bacon R. Growth, structure, and properties of graphite whiskers. Journal of Applied Physics. 1960;31:283-290. DOI:10.1063/1.1735559

29. Bandow S. Radial thermal expansion of purified multiwall carbon nanotubes measured by X-ray diffraction. Japanese Journal of Applied Physics. 1997;36:L1403L1405. DOI:10.1143/JJAP.36.L1403

30. Shioyama H, Akita T. A new route to carbon nanotubes. Carbon. 2003;41:179-181. DOI:10.1016/ S0008-6223(02)00278-6
31. Terrones H, Hayashi T, Munoz-Navia M, Terrones M, Kim YA, Grobert N, Kamalakaran R, Dorantes-Davila J, Escudero R, Dresselhaus M, Endo M. Graphitic cones in palladium catalysed carbon nanofibers. Chemical Physics Letters. 2001;343:241-250. DOI:10.1016/S0009-2614(01)00718-1

32. Mordkovich VZ, Baxendale M, Yoshimura S, Chang RPH. Intercalation into nanotubes. Carbon. 1996;34(10):1301-1303. DOI:10.1016/0008-6223(96) 82802-8

33. Harris PJF, Tsang SC, Claridge JB, Green MLH. High resolution electron microscopy studied of a microporous carbon, produced by arc evaporation. Journal of the Chemical Society, Faraday Transactions. 2010;90:2799-802. DOI:10.1002/chin.199504005

34. Ge M, Sattler K. Observation of fullerene cones. Chemical Physics Letters. 1990;220:192-196. DOI: 10.1016/0009-2614(94)00167-7

35. Muñoz-Navia M, Dorantes-Dávila J, Terrones M, Terrones H. Ground-state electronic structure of nanoscale carbon cones. Physical review B. 2005;72:235403:1-7. DOI:10.1103/PhysRevB.72.235403

\section{Информация об авторах / Information about the authors}

Кульницкий Борис Арнольдович, доктор физикоматематических наук, главный научный сотрудник, Технологический институт сверхтвердых и новых углеродных материалов (ТИСНУМ), Троицк, Москва, Российская Федерация; ORCID 0000-0001-5482-3123; e-mail: boris@tisnum.ru

Пережогин Игорь Анатольевич, кандидат физикоматематических наук, старший научный сотрудник, ТИСНУМ, Троицк, Москва, Российская Федерация; ORCID 0000-0002-8930-4806; e-mail: Iap1@mail.ru Батов Дмитрий Викторович, кандидат физикоматематических наук, ученый секретарь, ТИСНУМ, Троицк, Москва, Российская Федерация; AuthorID (Scopus) 36828098100; e-mail: d.batov@tisnum.ru

Бланк Владимир Давыдович, доктор физико-математических наук, научный руководитель, ТИСНУМ, Троицк, Москва, Российская Федерация; AuthorID (Scopus) 7005096766; e-mail: vblank@tisnum.ru

Альшевский Юрий Львович, кандидат физико-математических наук, научный сотрудник, ТИСНУМ, Троицк, Москва, Российская Федерация; AuthorID (Scopus) 6504159622; e-mail: Alshev.Yura38@mail.ru
Boris A. Kulnitskiy, D. Sc. (Physics and Mathematics), Chief Research Officer, Technological Institute for Superhard and Novel Carbon Materials (TISNCM), Troitsk, Moscow, Russian Federation; ORCID 00000001-5482-3123; e-mail: boris@tisnum.ru

Igor A. Perezhogin, Cand. Sc. (Physics and Mathematics), Senior Researcher, TISNCM, Troitsk, Moscow, Russian Federation; ORCID 0000-0002-89304806; e-mail: Iap1@mail.ru

Dmitriy V. Batov, Cand. Sc. (Physics and Mathematics), Academic Secretary, TISNCM, Troitsk, Moscow, Russian Federation; AuthorID (Scopus) 36828098100; email: d.batov@tisnum.ru

Vladimir D. Blank, D. Sc. (Physics and Mathematics), Research Supervisor, TISNCM, Troitsk, Moscow, Russian Federation; AuthorID (Scopus) 7005096766; email: vblank@tisnum.ru

Yuriy L. Alshevskiy, Cand. Sc. (Physics and Mathematics), Research Associate, TISNCM, Troitsk, Moscow, Russian Federation; AuthorID (Scopus) 6504159622; e-mail: Alshev.Yura38@mail.ru 